\title{
LAKI-LAKI SEBAGAI SEKUTU GERAKAN PEREMPUAN
}

\author{
Nur Hasyim \\ Universitas Islam Negeri (UIN) Walisongo Semarang \\ e-mail: nur_hasyim@yahoo.com
}

\begin{abstract}
Abstrak
Paper ini mengkaji tentang laki-laki yang menjadi sekutu bagi gerakan perempuan. Melalui proses sensitisasi atau penyadaran, laki-laki sebagai kelompok dominan dalam penindasan atas dasar jenis kelamin dapat memiliki kesadaran feminis atau menjadi bagian dari perjuangan perempuan dalam menghapus ketidakadilan berbasis gender. Namun demikian, posisi laki-laki dalam gerakan perempuan problematis karena privilese dan kekuasaan yang melekat kepada lakilaki sementara keterlibatan mereka dalam gerakan perempuan adalah untuk mendorong laki-laki berhenti menikmati privilese dan kekuasaan sendiri dan selanjutnya mendorong laki-laki untuk mau berbagi privilese dan kekuasaan dengan perempuan. Paper ini mengupas arah gerakan laki-laki sebagai sekutu gerakan perempuan untuk memastikan bahwa gerakan laki-laki pro-feminis ini benar-benar untuk pencapaian keadilan yang hakiki yakni untuk pencapaian keadilan bagi laki-laki dan perempuan dan bukan untuk menciptakan dominasi baru laki-laki dalam ruang-ruang politik perempuan.
\end{abstract}

Kata Kunci: gerakan perempuan; patriarkhi; privilese; kekuasaan; maskulinitas; sekutu gerakan perempuan

\section{A. Pendahuluan}

Munculnya sekutu kelompok tertindas dari kelompok dominan atau penindas telah menjadi bagian dari sejarah kehidupan manusia. Dalam sejarah kolonisasi, ada orang-orang dari kaum penjajah yang memprihatinkan perlakuan kaumnya kepada kelompok terjajah atau pribumi seperti Douwes Dekker, orang Belanda yang mencintai Indonesia dan menulis kritik atas perlakuan bangsanya terhadap pribumi. Demikian halnya dengan gerakan anti rasial, tidak sedikit orang kulit putih yang menyuarakan penghentian bentuk penindasan atas dasar warna kulit ini.

Pun demikian dengan persolan penindasan atas dasar jenis kelamin. Bentuk penindasan yang dibongkar oleh gerakan feminisme ini menempat- 
kan laki-laki sebagai kelompok dominan yang menikmati beragam privilese, memegang kekuasaan di berbagai ranah kehidupan dan menindas kelompok perempuan. Seperti halnya gerakan anti-kolonialisme dan anti rasialisme yang menyadarkan sebagian kelompok dominan dan penindas atau kelompok kulit putih dan penjajah tentang penindasan yang mereka lakukan serta menumbuhkan solidaritas di antara mereka terhadap kelompok yang tertindas, gerakan feminisme juga menumbuhkan kesadaran kepada sebagian kelompok laki-laki akan bentuk penindasan yang dialami perempuan yang merupakan penindasan paling lama dan paling mendasar dalam kehidupan manusia. Kesadaran ini selanjutnya menggerakkan mereka menjadi sekutu (allies) atau menjadi bagian dari gerakan perlawanan terhadap segala bentuk penindasan terhadap perempuan.

Munculnya kesadaran feminis dari kelompok laki-laki ini melalui berbagai proses. Proses ini disebut oleh Casey and Smith sebagai men's pathways to involvement in anti-violence works. Sebagai awal dari serangkaian proses itu adalah proses sensitisasi (penyadaran) yang dapat terjadi melalui berbagai cara di antaranya diasuh dan dididik olef feminis, menyaksikan penindasan yang dialami orang-orang dekat seperti ibu, saudara perempuan atau teman perempuan, atau terlibat dalam gerakan hak asasi manusia atau perlawanan terhadap terhadap berbagai bentuk penindasan manusia atas manusia lainya. ${ }^{1}$ Hal serupa juga ditemukan oleh Hasyim ketika mengevaluasi gerakan Aliansi Laki-Laki Baru sebuah gerakan laki-laki pro perempuan di Indonesia bahwa keterlibatan laki-laki dalam aliansi ini setelah mereka mengalami penyadaran akan penindasan yang dialami oleh perempuan di sekitar mereka. ${ }^{2}$

Namun demikian, dalam perjalanannya, posisi kelompok dominan atau penindas sebagai sekutu dari kelompok tertindas untuk mengakhiri penindasan yang dilakukan oleh kelompoknya ini selalu tidak mudah karena privilese dan kekuasaan yang melekat pada dirinya sebagai bagian dari kelompok penindas. Demikian hal dengan laki-laki yang terlibat dalam gerakan perempuan atau gerakan untuk keadilan gender, karena inti dari

${ }^{1}$ E. Casey \& Smith, T., “How Can I Not? Men's Pathways to Involevement in AntiViolence Against Women Works". Violence Against Women, 16 (8), 2010, h. 953-973.

${ }^{2}$ N. Hasyim, “How Far Can Men Go? A Studi of Men Movement to End Violence Against Women in Indonesia", (Wollongong: University of Wollongong , 2014). 
gerakan tersebut adalah mengakhiri dominasi privilese dan kekuasaan lakilaki atas perempuan untuk selanjutnya mendorong laki-laki untuk berbagi privilese dan kekuasaan tersebut atau dengan kata lain laki-laki meletakkan kepentingan perempuan atau kelompok tertindas di atas atau menjadi kepentingan diriya sendiri. Lebih jauh meminjam definisi Broido tetang social justice ally (Sekutu Keadilan Sosial) sebagai "anggota kelompok dominan atau kelompok mayoritas yang bekerja untuk mengakhiri penindasan dalam kehidupan dan karir profesionalnya melalui dukungan dan sebagai advokat dari kelompok yang tertindas". ${ }^{3}$

Posisi pelik laki-laki dalam gerakan perempuan adalah karena di saat mereka mendeklarasikan diri sebagai laki-laki feminis, pro-feminis atau properempuan struktur masyarakat di mana mereka hidup belum berubah artinya mereka tidak serta merta berhenti menikmati perlakuan istimewa dan kekuasaan yang diberikan kepada mereka karena privilese dan kekuasaan itu telah melembaga dan tanpa aksi yang jelas untuk menunjukkan perlawanannya terhadap privilese dan kekuasaan yang mereka nikmati itu, sikap dan tindakan mereka dalam kehidupan sehari-hari akan menjadi bagian dari pelestarian privilese dan kuasa laki-laki bahkan di saat mereka tidak melakukan apapun atau diam.

Sebagai laki-laki, mereka yang mendeklarasikan diri sebagai feminis, pro-feminis atau pro-perempuan, suka atau tidak suka tetap memiliki akses yang lebih terhadap sumber daya, tidak memiliki hambatan kultural untuk berperan di berbagai sektor, tidak memiliki kerentanan terhadap kekerasan, dan memiliki peluang yang lebih besar untuk dapat menempati posisi-posisi strategis di berbagai lembaga baik pemerintah, swasta maupun organisasi masyarakat sipil. Dengan posisi ini, laki-laki feminis, pro-feminist atau properempuan memiliki banyak jebakan. Alih-alih menghentikan penindasan yang dialami oleh perempuan, keterlibatan mereka dalam gerakan perempuan berpotensi membuat mereka tergelincir dalam proses pelanggengan penindasan itu sendiri dan yang lebih berbahaya adalah justru penindasan itu terjadi dalam ruang politik yang selama ini telah dibangun dan diperjuangkan oleh perempuan seperti dalam gerakan perempuan dan gerakan anti kekerasan terhadap perempuan.

${ }^{3}$ Broido, E., "The Development of Social Justice Allies During College: A Phenomenological Investigation". Journal of College Student Development, 41(1), 2000, h. 3. 


\section{B. Peta Jalan Gerakan Laki-laki sebagai Sekutu Gerakan Perempuan}

Atas dasar kompleksitas posisi laki-laki feminis atau pro-feminis dalam gerakan perempuan atau gerakan feminis, menjadi penting untuk merumuskan peta jalan gerakan laki-laki pro-feminis atau gerakan laki-laki pro-perempuan di Indonesia. Peta ini penting untuk menjaga arah (visi) gerakan dan untuk menilai pencapaian-pencapaiannya. Peta jalan ini juga untuk memastikan bahwa laki-laki yang menjadi sekutu perempuan itu dalam rangka untuk menjadi keadilan yang hakiki untuk laki-laki dan perempuan. Peta jalan ini setidaknya mencakup empat titik pemberhentian sebagaimana tergambar pada Gambar 1:

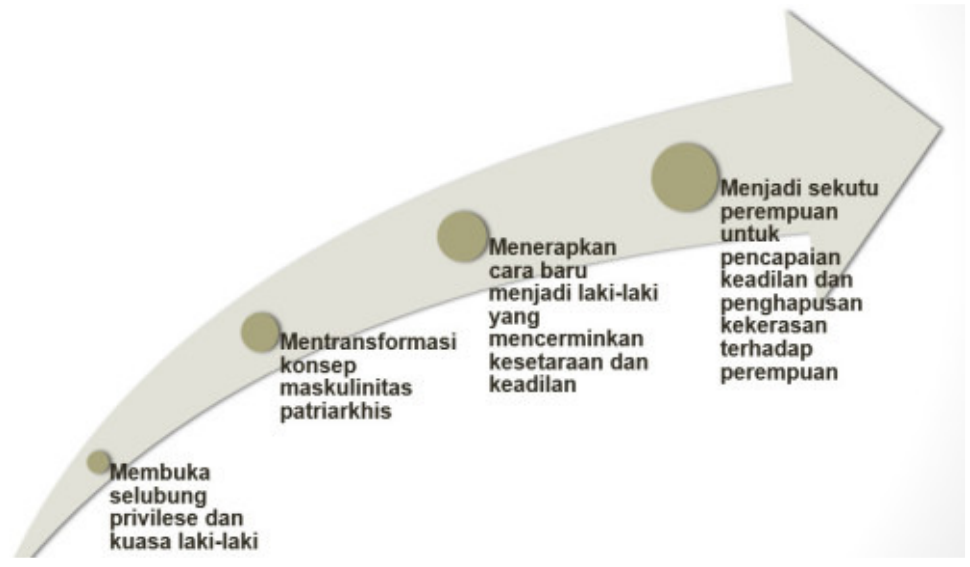

Gambar 1.

Peta Jalan Gerakan Laki-Laki Pro-Feminis

Pemberhentian ini saya bayangkan sebagai tahapan yang musti dicapai sebelum melangkah menuju pemberhentian berikutnya dan saya sebut sebagai pemberhentian karena pada setiap tahapan ini membutuhkan proses lama, usaha, sumberdaya, fokus dan kerja-kerja perubahan sosial.

\section{Pemberhentian Pertama, Membuka Selubung Privilese dan Kuasa Laki-laki}

Pemberhentian ini penting karena pemahaman dan kesadaran atas penderitaan korban sangat penting akan tetapi belum lengkap tanpa 
pemahaman atas pelembagaan privilese dan kuasa yang menyebabkan penderitaan dan penindasan tersebut. Mengutip pernyataan Bob Pease bahwa "kita tidak dapat memahami penindasan secara utuh tanpa memahami kelompok yang menindas (yang memiliki privilese dan kuasa)". ${ }^{4}$

Di antara yang membuat penindasan terhadap perempuan itu lestari karena laki-laki memahami perlakuan istimewa dan pemberian kuasa oleh sistem sosial patriarkhis sebagai sesuatu yang seharusnya atau hal yang normal. Laki-laki tidak memahami bahwa privilese dan kuasa itu diberikan oleh sistem sosial yang memihak kepada mereka. Laki-laki juga tidak memahami dan menyadari bahwa privilese dan kuasa yang mereka nikmati itu menimbulkan kesengsaraan perempuan dan kelompok lain yang tidak diuntungkan oleh sistem patraiarkhi. Maka agenda pertama dari gerakan laki-laki feminis, pro-feminis atau laki-laki yang menjadi sekutu gerakan perempuan adalah membuat privilese dan kuasa itu nampak (visible) bagi laki-laki. Karena tersembunyinya privilese laki-laki itu adalah bagian dari privilese itu sendiri.

Proses membuat privilese dan kuasa menjadi kasat mata di hadapan laki-laki memang tidak mudah. Di antara yang mungkin dilakukan adalah memunculkan pertanyaan-pertanyaan reflektif yang menggugah kesadaran laki-laki tentang privilese dan kekuasaan mereka. Di antara pertanyaanpertanyaan reflektif itu adalah:

1. Seberapa sering Anda merasa khawatir dilecehkan pada saat Anda berada di kendaraan umum?

2. Seberapa sering Anda merasa khawatir mengalami perkosaan ketika ada berjalan sendirian di malam hari?

3. Apakah Anda merasa harus meminta ijin untuk bekerja di luar rumah?

4. Pernahkan Anda terhambat mendapatkan pekerjaan karena jenis kelamin Anda?

5. Apakah Anda merasa bersalah ketika Anda keluar rumah sementara pekerjaan rumah belum beres?

${ }^{4}$ Bob Pease, Undoing Privilege Unearned Advantage in Divided World, (London: Zedb Books, 2010). 
6. Apakah Anda memiliki hambatan untuk mendapatkan pendidikan karena jenis kelamin Anda?

7. Apakah Anda memiliki hambatan untuk menempati posisi-posisi strategis karena jenis kelamin Anda?

Dengan pertanyaan tersebut laki-laki diajak untuk merenungkan sejauh mana mereka mengahadapi persoalan sebagaimana diungkapkan dalam setiap pertanyaan tersebut, selanjutnya laki-laki diajak untuk membayangkan jika pertanyaan-pertanyaan tersebut dilontarkan kepada perempuan dan membandingkan jawaban yang mungkin muncul dari perempuan. Dalam beberapa workshop (yang dilakukan oleh penulis sendiri) ditemukan bahwa perempuan akan memberikan jawaban berbeda dari laki-laki dan perbedaan ini karena perempuan tidak mendapatkan perlakuan istimewa seperti halnya laki-laki. Sebagian besar perempuan mengalami kekhawatiran akan dilecehkan atau akan mengalami perkosaan dan kekhawatoran ini tidak ditemukan pada laki-laki. Sebagian besar perempuan juga merasa terhambat karir professional mreka karena jenis kelamin mereka dan hal ini juga tidak dialami oleh laki-laki. Lebih lanjut sebagian besar perempuan memiliki beban peran domestic dan beban ini tidak dipikul oleh laki-laki.

Jawaban yang seragam pada sebagian besar perempuan dan laki-laki atas pertanyaan-pertanyaan tersebut menandakan bahwa bahwa privilese dan kuasa di satu sisi dan penindasan di sisi yang lain telah melembaga di dalam masyarakat kita. Di sadari atau tidak setiap kita baik laki-laki atau perempuan ikut andil melesatarikannya melalui praktek kehidupan kita sehari-hari.

\section{Pemberhentian Kedua, Mentransformasi Konsep Maskulinitas Patriarkhis}

Patriarkhi ditopang oleh dua komponen yakni maskulinitas hegemonik dan heteronormativitas. Maskulinitas hegemonik adalah konsep yang dipopulerkan oleh Raewyn Connell ${ }^{5}$ seorang ilmuwan sosial Australia yang kemudian menjadi rujukan utama dalam kajian-kajian maskulinitas. Maskulinitas hegemonik mengandaikan dalam setiap masyarakat memiliki konsep maskulinitas yang menjadi standard rujukan bagi setiap laki-laki.

${ }^{5}$ R. Connell, Masculinities. (Sydney: Allen \& Unwin, 2005). 
Setiap masyarakat memiliki karakteristik maskulinitas yang diidealkan yang berbeda dari masyarakat lainnya namun demikian secara umum maskulinitas hegemonik dicirikan dengan kekuatan fisik, dominasi, superioritas dan kekerasan.

Konsep ideal laki-laki dari setiap masyarakat ini ditengarai hanya sebagaian kecil laki-laki saja yang dapat memenuhinya dan sebaliknya tidak realistis bagi sebagian besar lainnya. Konsep maskulinitas ini jika diibaratkan dengan sumber daya, setiap laki-laki memiliki akses yang berbeda antara satu dengan yang lainnya dan kapasitas laki-laki mengakses ini tergantung pada warna kulit, kelas sosial, kepemilikan atas kapital dan sebagainya. ${ }^{6}$ Perbedaan akses inilah kemudian yang melahirkan hirarkhi di antara laki-laki. Ada laki-laki yang berada pada puncak herarki yakni mereka yang karena berbagai faktor pendukung sebagaimana telah disebutkan dapat memenuhi kriteria laki-laki ideal (maskulinitas hegemonik), pada sisi yang lain ada laki-laki yang memiliki kapasitas terbatas untuk memenuhi kriteria ideal sehingga berada posisi subordinat terhadap mereka yang berada di puncak yang disebut dengan maskulinitas subordinat. Meskipun demikian maskulinitas subordinat ini tetaplah memiliki kedudukan dan status lebih di bandingkan dengan perempuan. Dengan demikian, selain persoalan penindasan laki-laki atas perempuan, konsep maskulinitas hegemonik sejatinya berperan dalam mengungkap struktur penindasan antar laki-laki sendiri.

Patriarkhi berkepentingan dengan pembangunan konsep maskulinitas hegemonik ini karena hanya dengan membangun mitos laki-laki ideal, patriarkhi dapat memproduksi laki-laki yang superior dan dominan dan hanya dengan superioritas dan dominasi laki-laki, patriarkhi dapat lestari sehingga kontrol atas perempuan oleh laki-laki dapat dipertahankan. Konsep maskulinitas yang diciptakan patrirakhi untuk menopang dirinya inilah yang kemudian disebut sebagai maskulinitas patriarkhis.

Komponen kedua dari patriakhi adalah heteronormativitas yang dimaknai sebagai penerapan pola hubungan heteroseksual sebagai standar norma di dalam masyarakat. Hubungan-hubungan lain diluar heteroseksual

${ }^{6}$ Whitehead, SM., Barret, FJ., "The Sociology of Masculinity". In: S. B. F. Whitehead, ed. The Masculinities Readers. s.l.: Cambridge, 2001. 
dianggap sebagai devian atau penyimpangan. Sebagai standar norma dalam sistem sosial masyarakat maka terhadap apa yang dianggap menyimpang, masyarakat memiliki mekanisme penjagaan keseimbangan (latent maintenance mechanism) melalui pendisiplinan. Proses pendisiplinan terjadi melalui mekanisme penghargaan terhadap mereka yang tunduk dan patuh terhadap norma yang berlaku dan mekanisme hukuman, ekslusi, dan stigmatisasi terhadap mereka yang membangkang. Fenomena hujatan terhadap kelompok minoritas seksual dapat dilihat dari sudut pandang ini.

Selain berkepentingan terhadap maskulinitas hegemonik, patriarkhi juga berkepentingan terhadap penegakan heteroseksual sebagai norma (heteronormativitas) karena kontrol dan dominasi laki-laki atas perempuan hanya dapat dimungkinkan terjadi dalam realasi heteroseksual dan tidak dalam relasi lainnya. Dengan demikian maskulinitas hegemonik dan heteronormativitas berkelit dan berkelindan menopang bangunan patriarkhi.

\section{Pemberhentian Ketiga, Menerapkan Cara Baru Menjadi Laki- laki yang Mencerminkan Kesetaraan dan Keadilan}

Seperti yang telah diuraikan pada bagian sebelumnya bahwa laki-laki dalam kultur patriarkhi memahami dan meyakini konsep-konsep maskulinitas yang meneguhkan superioritas mereka atas perempuan seperti yang diinginkan patriarkhi. Pemahaman dan keyakinan akan konsep maskulinitas patriarkhis ini mempengaruhi konsep diri laki-laki atau bagaiamana laki-laki melihat dirinya sendiri dan bagaimana mereka melihat orang lain (laki-laki lain dan perempuan). lebih lanjut, konsep diri laki-laki pada gilirannya meregulasi perasaan, sikap dan perilaku dalam merespon situasi di luar dirinya termasuk mengatur pola relasi dengan orang lain. Pandangan bahwa laki-laki superior dari perempuan membuat laki-laki cenderung mengobyektifasi perempuan atau menilai negatif kepada laki-laki lain yang anggap lemah seperti perempuan.

Namun laki-laki tidak memahami dan menyadari bahwa laki-laki harus membayar ongkos dari tuntutan konsep maskulinitas patriarkhis. Memang konsep maskulinitas ini memberikan privilese, kuasa dan keuntungan material sebagai, meminjam istilah Raewyn Connell, deviden yang diberikan patriarkhi kepada laki-laki namun laki-laki harus membayar banyak hal di antaranya laki-laki harus merepresi emosi mereka untuk terlihat kuat dan tegar secara emosional, laki-laki harus kehilangan 
kedekatan dengan anak-anak mereka karena anggapan pengasuhan bukan tanggungjawab mereka, laki-laki harus rela dicurigai sebagai pelaku kekerasan yang dilakukan oleh sedikit laki-laki, laki-laki cenderung tidak fleksibel sehingga kelenturan mereka menghadapi perubahan menjadi lemah sebagai akibat pemahaman kaku tentang menjadi laki-laki sebagaimana ditawarkan oleh konsep maskulinitas patriarkhis, laki-laki harus terlibat dalam perilaku yang beresiko seperti perang, sebagai penyelamat saat bencana alam dan perilaku lainnya karena tuntunan konsep maskulinitas patriarkhis yang mengedepankan superiotitas, kekuatan dan kekerasan.

Dengan paparan tentang konsekuensi negatif yang harus ditanggung laki-laki atas konsep maskulinitas patriarkhis yang mereka yakini selama ini diharapkan laki-laki mulai untuk berfikir tentang cara lain untuk menjadi laki-laki. Cara yang membuat mereka menjadi lebih manusiawi dan memanusiakan orang lain. Mengiringi perubahan pemahaman dan keyakinan akan konsep laki-laki, gerakan laki-laki pro-feminis atau gerakan laki-laki sebagai sekutu perempuan perlu memandu laki-laki untuk berlatih cara bersikap dan berperilaku baru yang mencerminkan penghormatan dan penghargaan kepada sesama, komunikasi yang terbuka, memupuk empati, saling berbagi dan non kekerasan. Laki-laki dilatih dan dibiasakan diri untuk fleksibel, cakap mengasuh anak, mengerjakan pekerjaan domestik, mengelola emosi secara positif, komunikatif dan menggunakan cara-cara non kekerasan dalam menyelesaiakan konflik dan perbedaan.

Sikap dan perilaku baru seperti keterlibatan laki-laki dalam pengasuhan anak dan kerja-kerja domestik dan sebagainya sangat penting namun belum cukup, laki-laki pro-feminist harus melanjutkan perjalanan ke "pemberhentian keempat".

\section{Pemberhentian Keempat; Menjadi Sekutu Perempuan dalam Pencapaian Keadilan Gender dan Penghapusan Kekerasan terhadap Perempuan}

Menjadi sekutu bagi gerakan perempuan untuk pencapaian keadilan gender dan penghapusan kekerasan terhadap perempuan menandakan bahwa keadilan gender dan penghapusan kekerasan terhadap perempuan menjadi komitmen politik laki-laki (politik maskulinitas) yang berarti laki- 
laki menggunakan identitas maskulinitasnya untuk melawan penindasaan atas dasar jenis kelamin dan gender. Dengan menjadi sekutu bagi perempuan, laki-laki pro-feminis menegaskan perlawanannya terhadap penindasan yang dilakukan oleh laki-laki lain. Lebih jauh, perlawanan terhadap ketidakadilan terhadap perempuan ini tidak lagi menjadi komitmen individual laki-laki akan tetapi menjadi komitmen laki-laki sebagai kelompok dan secara terorganisir bergerak bersama gerakan perempuan untuk memperjuangkan tatanan masyarakat yang lebih adil dan nirkekerasan.

Namun merujuk kembali prinsip laki-laki (kelompok dominan/ penindas) sebagai sekutu perempuan (kelompok tertindas), bahwa laki-laki dalam gerakan perempuan harus menempatkan diri sebagai pendukung dan advocat yang memperjuangkan kepentingan perempuan. Hal ini karena gerakan laki-laki pro-feminis tidak untuk memberikan privilese dan kuasa baru terhadap laki-laki dalam ruang politik perempuan.

\section{Kesimpulan}

Laki-laki sebagai sekutu gerakan perempuan atau dalam bahasa lain sering disebut dengan keterlibatan laki-laki dalam gerakan perempuan telah menjadi fenomena gerakan sosial baik di dunia maupun di Indonesia. Fenomena ini meneguhkan bahwa keadilan gender dan penghentian penindasan terhadap perempuan itu mensyaratkan perubahan baik pada perempuan maupun pada laki-laki.

Pemberdayaan dan penguatan gerakan perempuan penting namun belum cukup tanpa diikuti dengan transformasi laki-laki. Namun demikian keterlibatan laki-laki dalam gerakan perempuan juga problematis karena posisi laki-laki yang dominan dalam struktur masyarakat patriarkhis, alihalih mendorong kesetaraan dan keadilan bagi perempuan, laki-laki yang terlibat atau menjadi sekutu gerakan perempuan--dengan segala privilese dan kekuasaan mereka yang melembaga dalam struktur masyarakat patriarkhis-- dapat terjebak dalam penciptaan dominasi baru dalam ruangruang politik perempuan. Karenanya visi laki-laki sebagai sekutu gerakan perempuan harus jelas yakni dioreintasikan kepada pencapaian keadilan yang hakiki bagi laki-laki dan perempuan sebagaimana telah diuraikan. Selain itu, Laki-Laki yang menjadi sekutu bagi perempuan juga harus membangun prinsip-prinsip yang menjadi rambu-rambu untuk memastikan 
pencapaian visi untuk pencapaian keadilan yang hakiki bagi perempuan dan laki-laki.[]

\section{Daftar Pustaka}

Broido, E., "The Development of Social Justice Allies During College: A Phenomenological Investigation". Joumal of College Student Development, 41(1), 2000.

Casey, E., Smith, T., How Can I Not? Men's Pathways to Involevement in AntiViolence Against Women Works. Violence Against Women, 16 (8), 2010.

Connell, R., Masculinities. Sydney: Allen \& Unwin, 2005.

Hasyim, N., "How Far Can Men Go? A Studi of Men Movement to End Violence Against Women in Indonesia". Wollongong: University of Wollongong, 2014.

Pease, B., Undoing Privilege Unearned Advantage in Divided World. London: Zedb Books, 2010.

Whitehead, SM., Barret, FJ., "The Sociology of Masculinity". In: S. B. F. Whitehead, ed. The Masculinities Readers. s.1.:Cambridge, 2001. 
